C2013, Elsevier. Licensed under the Creative Commons Attribution-NonCommercialNoDerivatives 4.0 International http://creativecommons.org/about/downloads (c) (†) $\ominus$ 


\title{
Foresight for Public Procurement and Regional Innovation Policy: the Case of Lombardy
}

\author{
Riccardo Vecchiato* and Claudio Roveda
}

\author{
Riccardo Vecchiato \\ Politecnico di Milano \\ Department of Management, Economics and Industrial Engineering \\ P.zza Leonardo da Vinci, 32 \\ 20133 Milano, Italy \\ Fax: +39223992720 \\ Phone: +39223993994 \\ Claudio Roveda \\ Politecnico di Milano \\ Department of Management, Economics and Industrial Engineering \\ P.zza Leonardo da Vinci, 32 \\ 20133 Milano, Italy \\ Fax: +39223992720 \\ Phone: +39223992783
}

Riccardo Vecchiato is Assistant Professor at the Department of Management, Economics and Industrial Engineering of Politecnico di Milano, Italy. In 2005 he has been visiting researcher at the Manchester Business School, University of Manchester. His main research fields are strategic planning and strategic management of technology and innovation. On these themes he has presented at international conferences and published on international journals like Technological Forecasting and Social Change, Technology Analysis and Strategic Management, International Journal of Foresight and Innovation Policy.

Claudio Roveda is since 1982 Professor of Industrial Economics and Business Administration at Politecnico di Milano, Italy, where, since 1999 to 2006, he has been President of the Centre for Technology Transfer. Since 2010 he is CEO of Cotec, Italian Foundation for Technological Innovation. His main research fields are strategic planning and research and innovation policy. He has published more than 100 papers, mainly on international journals like International Technology Analysis and Strategic Management, Journal of the Operations Research Society of America, Management Science, Technological Forecasting and Social Change, International Journal of Foresight and Innovation Policy.

*corresponding author: riccardo.vecchiato@polimi.it 


\title{
Foresight for Public Procurement and Regional Innovation Policy: the Case of Lombardy
}

\begin{abstract}
Public procurement can be a major source of innovation. The potential benefits of public procurement might be fully exploited through the acquisition not only of appliances which are already available in the market, but also of new appliances which are tailored to the specific needs of the local community and might be exported as well to the international markets. In this way, public procurement might allow to improve the services delivered to the local community and to increase the technological competitiveness of the local industrial and research system. In this context, regional foresight might help identify both long-term societal needs and the patterns of evolution of emerging technologies that can match these needs. The purpose of this paper is to illustrate, trough the recent experience of the regional government of Lombardy, the role of foresight for enhancing public procurement and innovation policy at the regional level.
\end{abstract}

Keywords: regional innovation policy, public procurement, foresight, demand and $R \& D$ management, innovation. 


\section{Introduction}

Public procurement can be a major source of innovation. When oriented towards innovative solutions that improve the "quality" of the services provided to the society, public demand has the potential to strengthen the industrial and economic system through the effective involvement of the many and different players that are at the basis of the generation, implementation and dissemination of new technologies (Dalpé et al. 1992; Edler and Georghiou, 2007; Porter, 1998).

In the 1970s, a number of empirical studies explored the meaning of public procurement of innovation (for an overview, see Mowery and Rosenberg, 1979; Rotwell, 1986). Rothwell and Gardiner (1989) showed that, over longer time periods, state procurement triggered greater innovation impulses in more areas than did R\&D subsidies. Geroski (1990, p. 183) also analysed the quantitative and qualitative meaning of state demand for innovation and concluded that procurement policy "is a far more efficient instrument to use in stimulating innovation than any of a wide range of frequently used R\&D subsidies".

Nonetheless, with a few exceptions, in the EU the potential (and challenges) inherent in the use of public procurement have been largely ignored in public policies, both conceptually and in practice. Some scholars have argued that the introduction of more stringent competitive regulations across the EU turned out to be a major driver of the declining use of this instrument (Edquist et al., 2000). Such decline is confirmed by statistics and empirical evidence, showing that procurement in the EU is taken into account four times less than in the US in civilian sectors and two times less in defence (Directors Forum, 2006).

This trend was discontinued in the mid 2000s, as a new interest has emerged in the context of demand-side approaches to innovation and, more concretely, in the use of public demand as an engine for innovation in some EU Member States (Edler et al. 2006). The emphasis has been put on the link between procurement and perceived under-investment in 
R\&D by the business sector. Edler and Georghiou (2007) argue that such interest in public procurement has been due to a sense that traditional supply-side innovation policies are insufficient to meet the challenges posed in promoting competitiveness. The way in which procurement has entered the policy agenda is itself an interesting issue. Following the work of an expert group, procurement for innovation was incorporated as an element of the European Commission's Research Investment Action Plan to raise R\&D expenditure to the 3\% Barcelona target (Georghiou, 2003, 2007; European Commission, 2003). Follow-up work includes a specific action to support the development and diffusion of information to public buyers (for example, on the best available technologies) and an initiative to set procurement in the broader context of "policy mixes", thereby exploiting synergies with other research and innovation policy measures, such as technology platforms.

Parallel to the renewed interest in the use of public procurement, a second research stream in the literature on innovation and research policy is increasingly emphasizing the importance of regions for innovation and growth. Porter's work on clusters clearly showed how geographical concentrations of competing and cooperating enterprises are linked by social and institutionalized networks that in turn facilitate learning, innovation and competitiveness (Porter, 1990; 1998). This work paved the way for the current growing interest in Regional Innovation Systems - RIS (Cooke et al., 2000; Asheim and Gertler, 2005). The RIS approach emphasizes the shift of innovation policies from the national to the regional level with particular attention to the interactive flows of knowledge between the different components and stakeholders of a regional system.

Following this shift, there is a clear need (and opportunity) for appropriate methods and tools, aiming at enhancing the formulation of a regional vision and a regional innovation strategy able to translate this vision into policy action, with respect to all the phases of the "policy cycle" (Georghiou, 2001; Roveda et al., 2004; Smits and Kuhlmann, 2004). In 
particular, a tool which is benefiting of growing popularity is 'Regional Foresight' (Koschatzky, 2005; Roveda and Vecchiato, 2008).

The main objective of this paper is to link the research streams of public procurement, foresight, and regional innovation policy. We ask: How do policy makers that have responsibility for regional innovation strategy design and use foresight for informing public procurement for innovation? The case of the A3T (Analysis of Application Areas and Technologies) project that has been carried out in the late 2000s and early 2010s by the regional government of Lombardy is very helpful to explore this research question. The A3T project was conceived by the regional government of Lombardy in order to combine public procurement with its research, development and technology innovation (RDTI) strategy, and was based on an exercise of (regional) foresight.

The paper is structured as follows. The section 2 briefly reviews the relevant literature on regional foresight and public procurement. Section 3 describes the main challenges (and opportunities) to tackle for carrying out public procurement at the regional level, and the potential role of foresight for overcoming these challenges (and exploiting opportunities). Section 4 illustrates methodology, process and outputs of the A3T project, by focusing on the outcomes of the foresight exercise and its impact on public procurement. Section 5 discusses the general insights and implications for foresight and public procurement for innovation we drew from the A3T project and finally section 6 outlines future research avenues.

\section{The role of public procurement, regions and foresight in innovation policies}

This section provides a brief overview of the three research streams in literature on $R \& D$ and innovation policy that are relevant for the purpose of the paper, i.e. public procurement, the role of regions for RTDI in the EU, and foresight. 


\subsection{Demand-side innovation policies and public procurement: a new wave of}

\section{interest}

The interest in demand-side innovation policies as an approach for fostering competitiveness is quite popular: such policies attempt to complement the traditional supply-side measures. Supply-side measures refer to the provision of firms with resources, technological knowledge and/or capabilities to innovate: this can be achieved by means of grants, loans, tax incentives, consultancy support, and various forms of support for equity and debt guarantees. By contrast, demand -side innovation policies can be defined as a set of public measures which attempt to pull through innovations and the diffusion of innovations (Edler, 2008, 2010). According to Hollanders and Arundel (2007), the rationale for demand-based policies lies on four pillars: the overcoming of system failures which become manifest in a set of concrete bottlenecks (e.g. information and adoption problems in innovation markets, high entry costs blocking future scale and network effects, lack of skills for absorbing new technologies); the serving of societal needs and the capture and translation of societal needs into articulated market demands; the achievement of productivity gains through the modernization of industrial assets; the incentive for regional and national companies to implement forefront innovation.

The tool box for demand-side innovation policy encompasses a wide range of approaches: public procurement, i.e. the acquisition of goods and services by government or public organizations; direct support to private demand (e.g., demand subsidies); improvement of demand competence and support of demand articulation (i.e. trying to better understand societal preferences and how they link to technological trajectories); standards and regulations (e.g. for the environmental quality of products and processes); support to clusters 
and platforms, by mobilizing actors and networks and bringing together demand and supply for innovation (Edler, 2008; Georghiou and Harper, 2008).

Public procurement in particular has received a wide interest in recent years (Edler and Georghiou, 2007; Georghiou 2008; Wilkinson et al., 2005). Porter (1990) argued that such approach can act as a positive force for upgrading national competitive advantage, by: providing early demand for advanced new products and services; leading government to act as a demanding and sophisticated buyer; facilitating innovation and encouraging competition. These conditions are mutually reinforcing and each may have its greatest significance at different stages of an industry's evolution and depending on industry characteristics.

Uyarra and Flanagan (2009) emphasize the difference between 'regular' procurement and 'public technology' procurement. On the one hand, regular public procurement occurs when public sector organizations buy ready-made products for which no $R \& D$ is required and about which purchasing and supplier selection decisions can be made on the basis of readily available information about price, quantity, and performance, given the existence of standardized markets. On the other hand, public technology procurement occurs when "a public agency acts to purchase, or place an order for, a product—service, good, or systemthat does not yet exist, but which could probably be developed within a reasonable period of time, based on additional or new development work - e.g. R\&D - by the organization(s) undertaking to produce, supply, and sell the product" (Edquist and Hommen, 2000).

Major proponents of the use of public procurement increasingly refer to 'public technology procurement' as the most promising field of development for demand-side policies and generically use the term 'innovative procurement' or 'procurement for innovation' rather than simply 'technology procurement' in an attempt to reflect a broader view of innovation beyond R\&D (Edler and Georghiou, 2007). The basic premise for this overriding role of public procurement for innovation is that the public buyer can specify 
requirements that cannot be met from off-the-shelf goods or services and hence that an innovation is required to meet the demand. There is a potential double benefit in that the purchaser receives an innovative solution, while the supplier benefits from customers' feedback and an assured first purchase. An extension of this concept is the 'lead market', where there are sufficient buyers of the innovation willing to pay a premium or take additional risks and other factors such as regulations and competition are favourable. Lead markets thus do not only refer to publicly defined conditions, but also to conditions that are determined by the private sector. To put it simply, a lead market provides a launch platform for innovations which then may evolve to become cheaper and more effective so that they can become of interest to a larger number of customers and be rolled out to other (international) markets (Beise and Cleef, 2004). Von Hippel (1986: p.791) has explored user driven innovations in sectors such as scientific instruments and coined the term 'lead users' to refer to "users whose present strong needs will become general in a marketplace months or years in the future". In the context of public policies for innovation, the concept of lead users seamlessly extend to public agencies pioneering innovative requirements which will spread later.

Based on this increasing interest and awareness, in the last decade the role of public procurement for innovation has moved higher and higher on the agenda of European policymakers at all levels. Public procurement accounts for a significant proportion of overall demand for goods and services, which in the EU represents around 16\% of the combined EU15 GDP (European Commission, 2005). This interest in the use of public demand as a driver of innovation has become mainstream in innovation policy debates, a process encouraged by the recommendations of a number of inquiries, reports and policy documents (e.g. Edler et al., 2005; European Commission, 2005, 2007; Aho et al., 2006; Kok, 2004). At the national level, and taking the example of the UK and Germany, a number of policy statements have 
highlighted the importance of public procurement (HM Treasury, 2007; DIUS, 2008; OGC, 2004; Edler, 2008). Studies and/or promotional activities for innovative procurement have been carried out as well in Finland, in Netherlands, and in Portugal, Spain and Italy by joint efforts of the COTEC Foundations. ${ }^{1}$

However, despite this upsurge of interest, public procurement needs to conform with a particular legal and regulatory framework which strongly differentiates public procurers from private ones (i.e., firms and private citizens) and which points to a set of relevant challenges when it comes to make an effective and concrete use of this tool for fostering innovation and competitiveness. The first set of challenges is related to governance and coordination issues in public procurement. Ideally, public procurement should combine efficient purchasing (value for money) with better public services and products (functional specifications, improved performance); but for achieving this goal, policy and administrative practice must overcome many organizational barriers (Edler, 2010). A joint strategy is required which defines public demand as an innovation policy leverage and which clearly establishes coordination mechanisms. Further conditions required for the public purchase of innovation are risk taking, procurers with sound market knowledge, the right incentive structure to take the risk, experienced and sophisticated risk management activities and political decision makers which defend higher entry costs of innovation for the sake of life-cycle costing and improved functional performance. All these governance conditions are important for all countries, but they are even more relevant in the case of the European countries that are still in a stage of transition and learning towards a more cohesive Union (Edler, 2008).

The second set of challenges is related to transparency and fairness. A systematic, transparent, open and objective procurement process is a key requirement for public procurement of innovation (Edler, 2010). Companies need to feel that the competition is

\footnotetext{
${ }^{1}$ In October 2011 the Presidents and Directors of the three COTEC foundations met in Genoa (Italy) for debating on the issue of public procurement of innovation: reports are available online http://www.cotec.it/it/2011/10/vii-simposio-cotec-europa-2/
} 
based on clear criteria and that the best value for money ratio succeeds; this is a condition sine qua non to incentivize them to invest in innovation activities and to enter into the public market. Corruption, bribery and favouritism in public purchasing decisions thereby represent a severe hindrance for innovation procurement, especially since market newcomers face a high risk of unfair competition. Without open access and market entry into the public market, competition tends to be less innovative: Hollanders and Arundel (2007) clearly show that the variables 'trust' and 'corruption' are strongly correlated with innovation performance.

\subsection{Regional governments and RTDI policies}

Regional governments in the EU are taking an increasingly active role in the field of RDTI policies, by adding and integrating their own actions and resources to those of national governments and European Commission (Georghiou, 2001; Howell, 2005). A key reason for this trend is the explicit acknowledgment that institutions and networks of interactions are the key forces shaping the direction and rate of learning and innovation (Hirst, 1994). In this view differences in innovation performance at the aggregate level are linked to differences in institutional settings: the many and diverse components of institutional settings thereby should be carefully explored and taken into account for identifying best practices which support innovation and learning (Steen, 1999). Key components of institutional settings include (formal) institutions for coordination, business laws and regulations, patenting and technology appropriability regulations, technical standards, etc., or rather more informal institutional structures such as cultural and social norms. The identification of best practices should encompass the mutual relationships between key components and the exploration of the basic conditions (e.g., size of local firms, intellectual property rights, tax incentives for $\mathrm{R} \& \mathrm{D}, \ldots)$ which allow them to work in a given country or region. In this vein, the "cluster" concept formalized by Porter (1998) has been very influential in inspiring regional and local 
policies for gaining national "competitive advantage". In short, the argument of economic and social externalities in 'cluster' approaches suggests that geographical proximity (physical, economic, social) is important not just because of reduction of physical distance and associated transport and location costs, but also because it facilitates information exchange, lowers uncertainty, increases the frequency of interpersonal contacts, facilitates trust and diffusion of common values and beliefs - i.e. cultural and social norms that enable continuous learning and knowledge creation.

The new role of regional governments has been largely emphasized by the European Commission (Laranja et al., 2008). The Communication "Innovation in a knowledge-driven economy" (European Commission, 2000) expressly recognizes the importance of designing and implementing innovation strategies at regional level, which the Communication "The Regional Dimension of the European Research Area" (European Commission, 2001) and the Communication "Regional Policy contributing to smart growth in Europe 2020" (European Commission, 2010) analyzed thoroughly. The former Communication explains how a research strategy able to deal with the specific situations and features of a region could be the most adequate approach: "first, by reinforcing the regional dimension of national research and innovation policies and harmonizing them with Regions' socio-economic needs; and second, by orienting these policies to reinforce Regions' research and innovation capacity, strengthening their ability to act as engines for economic and technological development." Finally, the European Commission recently promoted the 'Smart Specialisation' platform initiative for "developing a vision, identifying competitive advantage, setting strategic priorities and making use of smart policies to maximise the knowledge-based development potential of any region, strong or weak, high-tech or low-tech". ${ }^{2}$

\footnotetext{
${ }^{2}$ Smart Specialisation platform for regional development (http://s3platform.jrc.ec.europa.eu/home;jsessionid=QfcZRGpBdgLlpK9jYGmbZyp9FjXnmVCYjQcN2mG2R BF6yGny1Xcc!116563854!1359374785015).
} 
According to the vision of the European Commission, when referring to regions, the local administrative units are expected to act as a bridge between the EU, national and subregional levels, and between all the players of the local RDTI system (local authorities, universities, firms, etc.). Some of the priorities of the regional RDTI policies concern technology transfer from the local scientific institutions (mainly universities) to the local industry (mainly SMEs), and the establishment of cooperative networks among academia, research labs, financial institutions and firms for fostering the creation of new knowledge based firms (Flanagan et al., 2011).

\subsection{Foresight for Regional RTDI and Demand-Side Innovation Policies}

Following the increasingly relevant role of regions in setting up the RDTI agenda, there is a clear need (and opportunity) for new methods and tools able to organically support the regional "policy cycle" (Smits and Kuhlmann, 2004): a tool which is receiving growing attention is foresight.

"Foresight" is defined as "a systematic, participatory, future intelligence gathering and medium-to-long-term vision-building process aimed at present-day decisions and mobilising joint actions" (Renn and Thomas, 2002, p. 11). Foresight now covers a wide range of approaches and methodologies which aim at improving future-oriented decision-making and informing priority setting in RTDI (Colof and Smith, 2010; Martin, 2005; Porter et al., 2004) and has become quite popular among the scientific community and policy decision makers (Edler et al., 2003; Fildes, 1991; Hanney et al., 2001).

In the public sector the first foresight projects have been carried out at national level (Breiner et al., 1994; Rejis, 1994; Smith, 2004; for a general review, see Gavigan and Scapolo, 1999). Regional foresight was established more recently: it is the implementation of the five essential features of foresight - anticipation, participation, networking, vision and 
action - at smaller territorial scales than the wide and long experienced national ground. The term "region" may refer to a federal state, a metropolitan area or some other sub-national aggregation with an historical and economic identity or a distinctive geography (May, 2009). Regional foresight is thereby not a single methodology, but rather the combination of different methods and approaches fulfilling the task of helping regional stakeholders to deal with the future (Koschatzky, 2009).

Since the early 2000s, the European Commission has funded a large number of regional foresight projects, mainly focused on research and innovation and economic development: relevant examples are the FOREN ${ }^{3}$ project and $\mathrm{FUTURREG}^{4}$. A recent project for mapping foresight activities in Europe found that almost half of the exercises were regional and that their percentage was growing (Popper et al., 2006; Butter et al., 2008).

On the one hand, foresight might obviously play a key role in enhancing demand-side innovation policies, by helping public decision makers to identify long term societal needs and articulating them into the marketplace. On the other hand, scanning through the foresight exercises in the EU countries in the last decade, one must concede that, despite their large number, there are only a few and isolated cases focusing on future societal demands. Most foresight exercises actually concentrate on the supply-side, even if they include wider institutional contexts and link research and technology priorities to societal goals. Usually these studies have asked for future directions of the science base and how priority setting in this field can be guided. ${ }^{5}$

\footnotetext{
${ }^{3}$ The FOREN project involved 26 partners, led by a team from Spain, France, UK and Italy, which produced a Practical Guide to Regional Foresight that was made available in several EU languages (Gavigan et al., 2001). This document provides guidance on how foresight can be used in regions and includes several examples of its use in France, Spain, Germany, Italy and the UK.

${ }^{4}$ FUTURREG Futures for Regional Development (www.futurreg.net).

${ }^{5}$ That's exactly the case of the large number of national critical technologies foresight exercises that have been implemented throughout the 1990s and 2000s, such as the Dutch '98 "Technology Radar", the US '95 "White House Office of Science \& Technology Policy, Critical Technologies 1995” and '98 "New Forces at Work Industry views critical technologies - Office of Science Technology Policy, RAND Critical Technologies Institute", the French '95 "Technologies clés 2000" and 2000 "Technologies clés 2005", the Italian "National Priorities of Industrial Research" ( $1^{\text {st }}$ Report 1996 and $2^{\text {nd }}$ Report 2004) the German "96 "Technology on the
} 
On the contrary, there are very few examples of foresight studies that have been designed to agree on clear and specified demand issues and to take such issues as starting point for RTDI policy initiatives. At the national level, that's the case of the programmebased package in the Netherlands for selecting and developing focused application areas such as nano-electronics and food (van Rijswijk et al., 2008); the foresight experience in Germany for the development of a lead vision concerning emerging application areas (Bunkowski et al. 2011; Cuhls, 2008); the eGovernment foresight exercise in Bulgaria conducted in the context of the European FORETECH project ${ }^{6}$; and, outside Europe, the Health Foresight Initiative in Canada (Macklin and Soroka, 2011). At the regional level, significant examples are the Regional Infrastructure Foresight method developed for enhancing urban water management planning in the Swiss region of Kiesental (Stormer et al., 2009); the innovation policy roadmapping concept designed for adapting the traditional technology roadmapping and addressing critical innovation policy challenges in such application fields as building and construction (Ahlqvist et al., 2011); and the Innovation Foresight project designed for identifying users' specific needs and possible lead user ideas concerning digital television in Flanders (De Moor et al., 2011).

The common thread in all of these demand-side oriented foresight exercises is the development of a common vision or technology roadmap to: inform builders of clusters or platforms about the various kinds of linkages which can bind them together in future market and technology development (e.g., van Rijswijk et al., 2008); inform regulators of potential technological and/or socio-economic situations which regulation may promote (e.g., eGovernment foresight exercise in Bulgaria); or improve demand articulation and support demand articulation (De Moor et al., 2011). However, with the only exception of Ahlqvist et

\footnotetext{
Threshold of the $21^{\text {st }}$ Century"; and that's the case for instance of the RISE (Research, Innovation and Economic Development) critical technologies foresight exercise in Lombardy (Gavigan and Scapolo, 1999; Roveda et al., 2007).

${ }^{6} \mathrm{http}: / /$ foretech.online.bg
} 
al. (2011), all these foresight exercises do not explicitly take into account the use of public procurement for innovation. In particular, scholars left unexplored two specific issues which, according to Georghiou and Harper (2008), need to be thoroughly addressed in order to enhance the use of foresight approaches for successful public procurement of innovation.

The first issue concerns the process of informing public decision makers of the most promising options which might offer innovative forms of supply. Known as the market survey or technical dialogue, this activity takes place prior to the procurement process: scholars should investigate whether and how the use of foresight approaches might allow procurers to open up their thinking to technical solutions of which they may not have been aware.

Second, in the same way that new solutions may have been out of procurers' horizon, there is also the possibility that suppliers are not aware of opportunities for innovation and that procurers are not aware of the full range of potential suppliers. Scholars should investigate whether and how foresight approaches might foster network building and thereby might help to solve these pitfalls. In sum, Wilkinson et al. (2005) explain the main challenges inherent in the use of foresight for public procurement as follows: "The emphasis we have placed upon detecting needs at an early stage and of communicating these to suppliers brings to the fore the idea of using foresight to create a common vision as a framework in which purchaser and supplier can agree on the likely trajectories of innovation. Subsequently, these can be used as a basis for functional specifications that stimulate innovation and require $R \& D$ to achieve them."

\section{Foresight for public procurement and regional RTDI: exploring opportunities and challenges through the A3T project}


Literature review clearly shows that extant research on public procurement, regional RTDI and foresight developed as quite separate streams. Scholars generally omitted to provide empirical analysis and theoretical discussion of whether and how foresight practices and tools might be used for supporting public procurement for innovation at the regional level. Thus, there is a great opportunity to increase our understanding of the linkages and mutual influences between these research fields. On the one hand, the regional dimension is likely to help tackle the key challenges of public procurement for innovation related to governance and coordination issues and to transparency and fairness. Indeed, at the regional level public procurement might benefit from easier information exchange, increased frequency of interpersonal contacts, common cultural and social norms that foster continuous learning and mutual trust. A wide range of well-defined strategic actions thereby might be profitably implemented in the tradition of regional RTDI policy for enhancing public procurement in selected innovation fields and application areas. Some relevant examples are: a) establishment of bridging institutions between the government, the research sector and the industry, such as technology transfer centers, incubators, Science and Technology Parks; b) support to cooperative labs, research consortia; c) organization of links between universities and firms for planning research activities targeted at societal and market needs; d) dissemination of information about research results and know-how to firms and other regional stakeholders that might be interested in using them; e) promotion of the mobility of students and industrial researchers; f) support to the start-up of firms from universities.

On the other hand, the regional dimension might prevent public procurement from pursuing breakthrough technologies and radical innovation: the need to identify and to develop new solutions tailored to the specific demand of the regional community seems to collide with the opportunity to pursue large-scale and more general solutions with the potential to be exported to (and thereby to be shared with) the larger and diversified 
international markets. The regional dimension might jeopardize as well the availability of the financial, managerial (marketing and manufacturing) and scientific resources required for actually pursuing such radical and large-scale innovative solutions. Indeed, it is worth noting that all the most successful cases of procurement-induced innovations, like Internet and semiconductors in the USA and Japan, took place exactly at the national level, while at the regional level public procurement was oriented towards the regular purchase of ready-made products, like in the case of the Baltic region and the electronic ticket for public transport (Lember et al., 2008; Uyarra and Flanagan, 2009). As it fails to pursue technology innovation, regional public procurement may miss the key opportunity of selecting and supporting lead users, so providing early demand for advanced new products and services and thus acting as a concrete force for upgrading the competitive advantage of the industrial system of the region (and its whole nation).

In this paper we seek to extend current theory and to create new insights by describing and discussing a project that was recently completed by the regional government of Lombardy for experimenting the use of public procurement of innovation: the A3T (Analysis of Application Areas and Technologies) project which started in 2009 and is still ongoing. ${ }^{7}$ This demand side instrument was selected by the regional government in order to enrich the toolbox used for implementing the regional RTDI policy, up to that time focused on the supply side (subsidies to the public research sector, to R\&D projects stemming from firms, and to bridging institutions and activities between research and industry), so as to provide local citizens and firms with advanced products and services. The rationale at the basis of the

\footnotetext{
${ }^{7}$ Lombardy is the Italian region that has the highest concentration of people and businesses: it represents $15.6 \%$ of the overall national population with approximately 9 million inhabitants. The $24 \%$ of the population are under the age of 25 and $17.4 \%$ over 65. Local enterprises account approximately for $15 \%$ of the national GDP: there are an overall 740,000 firms based in Lombardy. Approximately 40\% of the Italian multi-nationals originate from the region, where 800 foreign and multi-national companies have their headquarters. Lombardy has the highest number of universities and the highest expenditure in scientific research in Italy. The total R\&D spending in the region) is $1,17 \%$ of GDP, divided up as follows: public sector $0,31 \%$, Government $0,12 \%$, University $0,19 \%$ and private sector $0,86 \%$ (updated: 2006 ).
} 
project was to use public procurement for improving the services delivered to the local community, and, at the same time, to increase the technological competitiveness of the local industrial firms.

The specific kind of public procurement of innovation implemented in the A3T project has been, at least initially, pre-commercial procurement: to date specific R\&D pilot projects are being implemented so as to provide prototypes. This choice was due to the novelty of this tool for the regional government of Lombardy, that needed to experiment with and learn about appropriate procedures. However, it is worth stressing that the main objective of the regional government has been to provide citizens and firms with final products and services: thereby the government has already committed itself to acquire the outputs of the R\&D pilot projects - after checking the compliance of the prototypes with the required specifications. An additional budget for final purchase has already been allocated.

The A3T project has turned out to be rather effective for selecting relevant emerging societal needs and for involving the local community of firms and research centers in the development of innovative solutions, thus providing a helpful basis for advancing empirical knowledge and theoretical discussion. Through the experience of Lombardy, we explore: How do policy makers that have responsibility for regional innovation strategy design and use foresight for informing public procurement for innovation? The A3T project provides a compelling example which allows to identify some basic guidelines and thereby a more general approach for framing public procurement for innovation and overcoming its traditional limits and criticalities (i.e. coordination, transparency, and fairness). In the next section we describe the main activities and outcomes of the A3T project whereas in the 
subsequent discussion section we point out the main insights and lessons we learnt from this case. $^{8}$

\section{The A3T project}

The A3T project was framed in the following phases (Figure 1): a) identification of innovative application areas (i.e. emerging relevant socio-economic needs of the local community of citizens and firms) which the regional government could satisfy through innovative products and services; b) evaluation of the application areas and selection of the most relevant ones; c) design of $R \& D$ pilot projects, that were intended to develop the emerging technologies required for the provision of the selected application areas; d) design of calls for implementing the R\&D pilot project and invitation of applicants.

From the organizational point of view, first of all a Steering Committee was established which supervised the overall A3T project and evaluated its intermediate and final results; the committee was made up by officers of the regional government of Lombardy. The Steering Committee appointed an executive team, made up by experts of IReR and researchers of Polytechnic of Milan, that designed and implemented the regional foresight exercise, outlined the operational programme, coordinated all the activities, provided background material, and edited the intermediate and final reports. The Steering Committee appointed also the large group of experts (about 60) who helped identify the emerging application areas. Experts were selected inside the local industrial and research community (first of all academia) according to such criteria as reputation, knowledge, vision, autonomy; their competences ranged from

${ }^{8}$ The findings of this paper are based on the collaborative research project undertaken by the authors, as they were members of the team of researchers from Polytechnic of Milan that, under the coordination of IReR the research institute of the regional government of Lombardy, carried out the A3T project (Adler et al., 2003; Greenwood and Levin, 1998). 
social sciences to technology and economy, mainly in such sector as food and agricolture, environment and energy, mobility, healthcare.

[Insert Figure 1 here]

\subsection{Phase 1: Exploration of application areas}

The first phase focused on the exploration of emerging application areas: these were defined as innovative products and services that broadly responded to growing social and economic needs of the local community of citizens and firms. Application areas related to macro fields such as healthcare and food and agriculture, for which the regional government of Lombardy bore major responsibility.

In the initial phase the project team interviewed the directors of the departments of the regional administration, responsible for healthcare, energy and environment, and food and agriculture in order to analyze the main policy guidelines they were pursuing and investigated the most critical problem areas they perceived in the mid and long term future. The closeness of regional administrators and policy makers lo local citizens and firms - due to their direct relationships with their electorate and their frequent participation to electoral meetings, round-table discussions (e.g. with Chambers of Commerce and trade associations), and public events - had allowed them to receive continuous feedback on changing social and economic needs. This feedback was shared with the project team, so that the consultation of regional policy makers provided a long list of application areas which could be developed in order to improve the situation of Lombardy.

All these application areas were afterwards analyzed together with the group of supporting experts that had been previously defined by the Steering Committee, in order to provide a rough assessment of the feasibility of developing the new technologies inherent in such applications through the scientific and industrial resources of Lombardy. The experts 
were allowed as well to advance their own proposals for other emerging applications areas, so that they complemented the original list received by the directors of the departments of the regional administration. Experts were consulted by the project team through a series of workshops and direct (personal) interviews.

This preliminary analysis was carried out on the basis of two main guidelines. The first guideline regarded the identification of application areas that: i) were of growing concern for local citizens and firms because a growing demand was expected to rise in the mid-term future; ii) required for their development high investments in research, not just the exploitation of technologies that were already available, with a time horizon of 3-5 years for the first experimental use.

The second guideline concerned the selection of the emerging technologies through which the application areas could be developed. According to the priorities set by the regional government in the early 2000s in its RDTI policy, emerging technologies were identified within the following areas: advanced materials, ICT, biotechnologies. The "granularity" of the selected technologies was set at the "family" level, i.e. rather aggregate, given the exploratory feature of the process, which was intended to provide a broad, preliminary description of the application areas. As an example, in the "advanced materials" field these technology families were taken into account: Superconductors, Semiconductors and Metal Matrix Composites; Structural Ceramics and Ceramic Matrix Composites; Polymers and Polymer Matrix Composites; Materials for Photonics and Magnetism; Modeling, Material Engineering \& Material Recycling.

The experts closely interacted with the officers of the regional government so that the application areas (and the related likely technological solutions) they suggested could be properly assessed in terms of their responsiveness and appropriateness towards the emerging needs of the regional community, as perceived and interpreted by the officers. 
The overall approach was consistent with traditional hallmarks of regional foresight exercises, such as the central role of experts, the integration of both qualitative and quantitative data, the iterative nature of the consultation process (Gavigan et al., 2001). At the end of this phase it was possible to identify the list of application areas and related technologies potentially relevant for the socio-economic and industrial system of Lombardy.

\subsection{Phase 2: Selection of application areas}

The second phase consisted in the evaluation and selection, within the list provided as the output of the first phase, of the key (i.e., most promising) application areas that could be actually acquired by the regional government by means of ad-hoc R\&D projects. Such selection was based on the relevance of the application areas and the feasibility of developing the new technologies they required.

Relevance (or attractiveness) refers to the capability of the application areas to foster social welfare and, at the same time, economic development of the regional system, especially in the industrial sector, as the target products and services could be potentially exported in the international (EU and global) markets. Relevance was evaluated with relation to two main dimensions: a) bright perspectives of exploitation in the international market; b) high coherence with the main policies of the regional government.

Feasibility (or position) links the application areas with the capability of the scientific and manufacturing system of Lombardy to develop them: a given application area and the required new technologies were considered feasible if they could be developed and implemented successfully by the scientific and industrial players of the region. Feasibility thus takes into consideration the resources and strategies of other regional or national systems and compares them with the case of Lombardy. More specifically, feasibility was evaluated with relation to these features: a) scientific knowledge that was available in Lombardy or 
could be built in a short time; b) capability of the local industrial system to develop the R\&D results up to the stage of lab prototype, and then to industrialise, manufacture and bring them to the local, national and EU markets. The evaluation of the appropriateness of the scientific and industrial resources of Lombardy was done with the option of integrating them with the resources available in other regions, both in Italy and abroad, which shared similar innovation strategies and programs.

Tables 1 and 2 describe the indicators (or criteria) used to operationalize the concepts of relevance and feasibility. The process of evaluation of the application areas and the related innovative technologies was iterative and lasted more than one year. The reasons for such an approach were the width of the investigation fields and the need to involve a large number of regional stakeholders, beyond (but together with) the group of experts that were originally selected by the Steering Committee. These stakeholders were meant to have a prominent role not only in the evaluation of the application areas but also in their subsequent implementation. They were selected from the public research sector (universities, scientific institutions, etc.) industry (large firms, trade associations, etc.) and sub-regional public bodies (municipalities, development agencies, etc.) through a spontaneous process of "passing the word" and reciprocal nomination - which stemmed from the original group of experts. Each stakeholder was provided with a report describing the application areas and the related innovative technologies, so that their evaluations for each indicator of relevance and feasibility could be collected.

Most indicators were calculated as the average of scores ranging from 1 (low performance) to 5 (high performance) on a Likert scale. All the evaluations provided by the experts and stakeholders were elaborated in terms of mean and variance; in case of significant variance for a given indicator, this was discussed with a panel of selected experts and stakeholders in order to investigate the main reasons behind such variance and to achieve, if 
possible, a consensus on its most likely value. A few indicators (for instance 'Size' of target markets) were open questions which required an estimation from the experts.

Some indicators which turned out to be particularly relevant were: 'Access to leadmarkets', which measures the availability in the regions of lead users for a given application; 'Size', which measures the size of the sectors/markets (at a regional, national and global scale) that are potentially interested in the application area; and 'Dynamics', which measures the likely growth in the mid and long term future of the target markets for the application areas (see Table 1 and 2). The combination of these three indicators allowed to figure out the application areas which were, at least potentially, the most promising for the regional system. A compelling example is provided by the application area 'Enhancement (functionalizing and nutritional enrichment) of traditional food products of Lombardy': given the delicious taste usually recognized at an international level - of Lombardy cooking (which thus provided easy access to 'lead markets' within the region) and the growing number of target customers such as elderly people throughout the EU and other industrialized countries (so that the size of target export market was expected to grow quickly), this application area clearly turned out to be very promising.

[Insert Table 1 here]

[Insert Table 2 here]

\subsection{Phase 3: Design of $R \& D$ pilot projects}

At the end of the evaluation process, each application area was translated into a few number of specific R\&D pilot projects. The latter ones detailed application areas in terms of concrete products and services and thereby of measurable objectives, technical features, 
technological developments, activities, timing, and likely implementation costs. The pilot projects were selected by the project team together with the group of supporting experts, that were involved through a series of workshops and direct (personal) interviews. The experts made available useful information in terms of qualitative and quantitative (statistical data), which helped the project team to prepare an initial draft for each pilot project. Such initial draft was afterwards circulated among the experts that provided their indications for further amendments and additions.

On the one hand, at the 'application area' level (i.e., in Phase 1 and 2) the granularity of technologies was set at the "family", i.e. rather aggregate, scale, because it turned out to be relatively easy to match broad societal needs with broad technological paradigms. On the other hand, scaling from general application areas to specific pilot projects required to make explicit the exact features of the innovative products and services to provide to the local community of firms and citizens. The design of such product and service features turned out to be a useful basis for shifting from broad technology domains (i.e., technology families) to the specific technologies required for matching them, so narrowing the granularity level of the technology foresight exercise. Such detailed technology requirements were clearly reflected in the $R \& D$ pilot projects.

The pilot projects were meant to be carried out at the regional scale; therefore more complex and large-scale applications that could be tackled successfully only at a national or supra-national level were disregarded. Table 3 summarizes the pilot projects that were selected and Table 4 describes briefly, as an example, the pilot project of "Functional Foods for elderly people" in the macro-field of Food and Agriculture.

[Insert Table 3 here]

[Insert Table 4 here] 


\subsection{Phase 4: Procurement calls}

The fourth phase was devoted to define the technical and economical requirements of the call procedures for the $R \& D$ pilot projects and to implement these calls.

By the end of 2011, the regional government selected three R\&D pilot projects within the Healthcare macro-field; these were: a) automated equipment for the towing of beds and stretchers; b) ICT-based remote systems for control, monitoring and home assistance to disable and chronically sick people; c) automated robotic systems for blood sampling. In March 2012, the regional government presented, through a series of workshops, these pilot $R \& D$ projects to a large number of local public and private stakeholders (firms, research centres, trade associations, universities, municipalities, etc.) in order to acquire their consensus and commitment to carry them out. An ad-hoc workshop was held for each pilot project.

Indeed a very large consensus from local firms and research institutions was achieved: more than 50 firms and research centres attended the workshops. Such consensus and wide interest boosted the regional government to translate the specific features of the pilot projects (i.e. objectives, activities, timing, products and service technical features) into the requirements of the "calls for $R \& D$ projects" that the regional government was going to fully finance. Each procurement call required applicants (likely a consortium of firms and research organizations) to provide a detailed description of the resources they were going to devote to the project: the selection of the "best" proposals basically took into account the "quality" of the applicants in terms of manufacturing, commercial and technological capabilities. The procurement calls thus took the shape of 'call for competencies' through which the regional government checked the ability of the candidate firms and research consortia to successfully 
execute the R\&D pilot projects. The budget for each call (i.e., pilot project) amounted to 750 thousand Euros.

The most relevant objective of this phase of (pre-commercial) public procurement was to acquire innovative and better performing solutions, at the level of R\&D prototype, for the selected application areas and to foster the technological competitiveness of local firms. The calls thereby required the candidate firms to be located in Lombardy, with at least a manufacturing site, while the scientific players could be located even outside the region (so allowing to get access to the best competences and knowledge for developing the pilot projects).

The deadline of procurement calls was the end of 2012. In the meantime, the regional administration proceeded with the selection of new pilot projects, the organization of new workshops for their presentation and the likely launch of the related procurement calls. Such gradual release of pilot projects was due both to the need of experimenting the overall process of public procurement and the recent limitations to the financial resources of the regional administration. However, the regional government already defined and allocated an additional budget for acquiring the final products and services resulting from $R \& D$ prototypes, so supporting, on a large scale, their industrialisation and commercialization. Indeed the main objective of the regional government was the provision of innovative and advanced applications able to satisfy the demand of local citizens and firms: the R\&D pilot projects were meant as an intermediate and instrumental step of public procurement, not as the final output. The purchase of ready-to-use products and services, developed from the prototypes of the pilot projects, will be the ultimate step of the A3T project, as the main rationale behind it.

\section{Discussion}


This paper adds to the debate on public procurement, foresight and regional RTDI policy (Adler and Georghiou, 2007; Cooke et al., 1997; Renn and Thomas, 2002).

The opportunity of using foresight for addressing public procurement of innovation by regional governments stems from the following factors: a) regional administrations in the EU have the institutional responsibility of providing a large set of services to citizens and firms in a number of areas (from healthcare to transportation); b) regional administrations can use their spending in these areas to acquire innovative solutions, i.e. products and services; c) regional administrations can support the development of advanced technologies through $\mathrm{R} \& \mathrm{D}$ projects in order to improve the performance of these products and services and, at the same time, reinforce the technological competitiveness of the local industry.

Obviously, the clear identification of future societal needs and their translation into a strategic agenda for research and technological innovation is an essential prerequisite for a $\mathrm{R} \& \mathrm{D}$ policy based on public procurement: there is no surprise thereby that prominent scholars and advisors of policy makers within the EU Commission have emphasized the role of foresight as a promising tool for performing this task (Edler, 2010; Georghiou and Harper, 2008; Wilkinson et al., 2005). Moving from theoretical discussion to empirical investigation, as we did in this paper, makes a further step in the research agenda: it provides descriptive data on the RTDI policy formulation practice of one of the main EU regions and how these practices change, through the use of foresight and public procurement of innovation, in response to increasing turbulence and complexity of social and technology dynamics.

To date, the A3T project is still ongoing. The implementation of public procurement involved so far only a limited number of pilot projects; the delivery of R\&D prototypes and the eventual purchase of innovative products and services, when industrialised, are yet to be completed, as well as the extension of public procurement efforts to other pilot projects and application areas. However, if one considers the main features of the A3T project in terms of 
goals, methodology and early outcomes, it is possible to draw some basic lessons with relation to the use of foresight for designing public procurement within the more general innovation policy of regional governments. We summarize here these lessons so as to outline the broad framework of a more general approach to designing public procurement, foresight and (regional) innovation policies.

The foresight methodology that was adopted in the A3T project is basically similar to the one used in many national critical technologies foresight studies; however, the foresight exercise within the A3T project remarkably differs from such exercises in that it focused, as its starting point, on emerging societal needs (i.e. application areas) and the possible technology-based innovative solutions (products and services) required for satisfying these needs, rather than on emerging technologies only. Furthermore, when compared with traditional supply-side national foresight exercises, the foresight methodology designed for the A3T project used a considerably smaller number of evaluation criteria, which were carefully selected in order to compare more easily the responses provided by the experts. The information gathered through these evaluation criteria proved to be able to support decisionmaking quite effectively by clearly highlighting priorities in application areas and their relationships with the emerging technologies required to fulfill them. By combining criteria of relevance and feasibility, such iterative evaluation process allowed to start from an overall overview of the societal and economic mid-term needs of Lombardy, as perceived by regional policy makers and stakeholders, and then to progressively go down to a limited set of innovative "application-technology" opportunities which could be translated into R\&D pilot projects.

On the one hand, the clear definition of all the indicators since the very beginning of the foresight exercise allowed to considerably increase the transparency of public procurement. These indicators allowed to set priorities in a rational way, by informing public decision 
makers and regional stakeholders of the most promising options for application areas potentially able to satisfy the local demand of citizens and firms and boost the international competitiveness of the regional industrial and research system (Georghiou and Harper, 2008).

On the other hand, the wide participation of regional stakeholders, first of all firms and trade associations, Chambers of Commerce, and other public agencies working in the territory, throughout the whole foresight exercise (mainly for the identification and evaluation of the application areas according to the indicators of relevance and feasibility) allowed to increase the awareness, commitment and consensus of the local community - some features which are typical of foresight exercises (Martin, 1995). Awareness and commitment enhanced in turn the fairness of public procurement, in terms of ease of access and participation to the calls (i.e., opportunity to apply for) (Edler, 2010). Drawing from the case of the A3T project, we thus suggest the following general insights:

Proposition 1. Policy makers that rely on foresight are more likely to select the longterm societal needs and application areas that are relevant to public procurement for innovation.

Proposition 2. Policy makers that rely on foresight are likely to enhance the participation, consensus and commitment of the local community of citizens and firms to public procurement for innovation.

Proposition 3. Policy makers that rely on foresight are likely to enhance the coordination, transparency and fairness of public procurement for innovation.

As a general remark, it is worth stressing the key role that the regional dimension of the foresight exercise, on one side, and the size of Lombardy, on the other, had for the successful implementation of public procurement for innovation. Based on the empirical evidence of the A3T project, we suggest that the regional level is an optimal dimension for involving the main stakeholders of the innovation process (public policy makers, public administration officiers, academia, large, medium and small firms) in the selection and evaluation of long term societal demands and their related solutions (Etzkowitz and Leydesdorff, 2000). Formal and informal institutional features, like social norms, favoured by geographic and cultural 
proximity, enhance strategic dialogue, mutual learning and trust relations (Roveda and Vecchiato, 2008). On the one hand, the proximity of regional administrators (i.e., public procurers) to local citizens and firms facilitated a better sharing and understanding of their future needs and requirements. On the other hand, strategic dialogue and trust relationships allowed a large involvement and direct participation of the local industrial and scientific community to the design and implementation of the pilot R\&D projects. The regional dimension thereby represents a relevant opportunity for overcoming such challenges of public procurement for innovation like coordination issues, transparency and fairness (Edler, 2008).

Drawing from the case of the A3T project, we thus suggest the following general lessons:

Proposition 4. The regional dimension of policy-making is likely to enhance the benefits of foresight to public procurement for innovation.

Proposition 5. The regional dimension of policy-making is likely to enhance the fairness and transparency of public procurement for innovation.

At the same time, despite its geographic proximity and cohesion, the social and economic system of Lombardy is large enough to allow it to pursue large-scale solutions with the potential to be exported (and eventually adapted) to larger international markets (see for instance the case of functional foods for elderly people illustrated by Table 4). So the regional market of Lombardy has good chances to be a lead market for the innovative solutions. i.e. 'markets with specific attributes that increase the probability that a locally preferred innovation design becomes internationally successful as well' (Beise and Cleff, 2004: p. 455). The identification of the lead market is in turn an essential prerequisite for sustaining the competitive advantage not only of the region, but of the whole nation to which it belongs, and thus for successful public procurement of innovation (Porter, 1990; Uyarra and Flanagan, 2009). Furthermore, the industrial system and the scientific community of Lombardy are 
large enough to have (or to achieve thanks to international partnerships with other players outside the region) the financial, scientific and manufacturing resources they need to develop and to market innovative products and services, thus retaining in the local territory the main benefits of public procurement.

Drawing from the case of Lombardy, we thus suggest:

Proposition 6. The regional dimension of $R \& D$ and industrial policy is likely to be consistent with public procurement for innovative technologies and products to be developed locally and to be exported into international markets.

Summing up, the A3T project thus allowed the regional government of Lombardy to achieve the following benefits. Firstly, it was able to define some relevant R\&D projects and to "acquire" the competences of the main players of the local research and innovation system for their implementation. Secondly, the identification of "application/technology" opportunities, their assessment and their eventual transformation into well defined pilot $R \& D$ projects were carried out through a wide and interactive consultation of players of the regional research and innovation system and of the regional administration. Panels of these players were set up and their work was facilitated and framed in a way that combined creative thinking and structured analysis and evaluation. So the relationships among the players of academia, industry and public administration could be built, reinforced and developed. Thirdly, by making use of an independent project team as advisor, planner and coordinator of the foresight exercise (phases 1, 2, and 3), the regional government was able to avoid the risk of being captured by suppliers, which might try to sell "off the shelf" products instead of responding to the needs of the government with new and tailored products. More than this, through the wide consultation of experts and representatives from the many stakeholders of the regional research and innovation system, the regional government took a mid-term outlook of the main possible patterns of technology developments and could identify the most promising application areas with relation to the specific goals and needs of its local 
community of citizens and firms. Recently, after the closing date of the procurement calls for the first R\&D pilot projects, the regional government of Lombardy has decided to reiterate the process in a new field, i.e. Mobility. Regional foresight and public procurement turned out to be new approaches for coordinating the actions of the many and different departments of the regional administration and for fostering their strategic dialogue with the local community. Firms and research institutions could exploit foresight and public procurement as new approaches for coordinating their efforts with each other and the regional administration, being involved in the formulation of innovation policies since the early stage of the identification and evaluation of research priorities.

\section{Conclusions}

The foresight methodology described in this paper can be useful to provide an effective blueprint for exploiting the inherent benefits and potential of public procurement and for enriching RTDI policy. However, two relevant issues need to be further explored, together with the trade-off between them.

The first one refers to the likely direct interest of the proposers of application areas and related pilot projects. This conflict of interest might affect the rules of public procurement in terms of transparency and, in particular, of equal opportunities of access for every market player. There is no doubt it is very difficult to combine these rules with the interest of industrial and research players (Edler, 2008; Edler et al., 2006; Georgiou, 2007).

The second issue regards the fact that better solutions to a given application area might actually be provided by industrial players (national, international) who do not operate in the region. So a dilemma arises: whether to purchase the best solution, wherever it comes from, so favouring the local society as a whole, but not the local industry; or to acquire a suboptimal solution from local firms, so favouring the development of the local industry at the 
expense of the society as a whole (Uyarra and Flanagan, 2009). In the case of the A3T project, the possibility of local firms to partner with other scientific players outside the region helped to mitigate this drawback.

A number of some more (even if minor) limitations should be pointed out, which are typical of foresight studies. First, in the evaluation phase the experts tend to concentrate their contribution on a specific technology or application area, so paying less attention to its interactions with others and missing the possible synergies and economies of scale. Second, quantitative information are not always available to the experts.

There is a validity and generalization problem regarding the methodology developed for the A3T project and the use of public procurement for promoting and supporting innovation at a regional scale. As we earlier suggested, the size of the region (in terms of its community as a lead market for innovation) has a crucial role: there are not many regions in the EU which are as large and advanced as Lombardy. However, the number of these regions is not marginal; it is enough to mention, as an example, the Four Motors of Europe (i.e., Lombardy, Rhone-Alpes in France, Catalunia in Spain and Baden-Württemberg in Germany). We thus think that the A3T project (and its methodology) is replicable in these leading European regions.

Future research might focus on exploring and implementing foresight for supporting public procurement of innovation and assessing its impacts on competitiveness at the national scale. The solution of the main problems that are inherent in the methodology we applied in the A3T project, requires considerable efforts, but still offers relevant opportunities for empirical investigation. A more robust theoretical understanding of the use of foresight for supporting public procurement of innovation could be gained as well, by means of literal and theoretical replications (Yin, 2003). 


\section{References}

Acs, Z.J., Anselin, L., Varga, A. 2002. Patents and innovation counts as measures of regional production of new knowledge. Research Policy 31 (7), 1069-1085.

Adler, N., Shani, A.B., Styre, A. 2003. Collaborative Research in Organizations: Foundations for Learning, Change, and Theoretical Development. Sage Publications, Thousands Oaks, CA.

Ahlqvist, T., Valovirta, V., Loikkanen, T. 2011. Innovation Policy roadmapping as a systemic instrument for policy design. Paper delivered to the Fourth International Seville Conference on Future-Oriented Technology Analysis (FTA) - Seville 12-13 May, 2011.

Aho, E. 2006. Creating an Innovative Europe. Report of the Independent Expert Group on R\&D and Innovation appointed following the Hampton Court Summit.

Asheim, B.T., Gertler, M.S. 2005. The geography of innovation: Regional innovation systems, in Fagerberg, J., Mowery, D., Nelson, R. (Eds) The Oxford Handbook of Innovation. Oxford University Press, Oxford, pp. 291-317.

Beise, M., Cleef, T. 2004. Assessing the lead market potential of countries for innovation projects. Journal of International Management 10(4), 453-477.

Blanc, H., Sierra, C. 1999. The internationalization of R\&D by multinationals: a trade-off between external and internal proximity. Cambridge Journal of economics 23, 187-206.

Breiner, S., Cuhls, K., Grupp, H. 1994. Technology foresight using a Delphi approach: a Japanese-German co-operation. R\&D Management 24, 141-153.

Bunkowski, A., Behlau, L., Cuhls, K. 2011. Fraunhofer future markets - from global challenges to dedicated, technological, collaborative research projects. Paper delivered to the Fourth International Seville Conference on Future-Oriented Technology Analysis (FTA) - Seville 12-13 May, 2011.

Butter, M., Brandes, F., Keenan, M., Popper, R. 2008. Editors' introduction to the European monitoring network. Foresight 10 (2), 3-15.

Calof, J., Smith, J. 2010. The integrative domain of foresight and competitive intelligence and its impact on R\&D management. R\&D Management 40, 31-39.

Cooke, P., Boekholt, P., Todtling, F. 2000. The Governance of Innovation in Europe, Pinter: London.

Cooke, P., Uranga, M.G., Etxebarria, G. 1997. Regional Innovation Systems: Institutional and organisational dimensions. Research Policy 26, 4, 475-491.

Cuhls, K. 2008. Foresight in Germany; in: Georghiou, L., Harper, J.; Keenan, M.; Miles, I., Popper, R. (ed.), The Handbook of Technology Foresight, 131-153. Edward Elgar, Cheltenham. 
Cuhls, K., Georghiou, L. 2004. Evaluating a participative foresight process: 'Futur - the German research dialogue'. Resarch Evaluation 13 (3), 143-153.

Dalpé, R., DeBresson, C., Ciaoping, H. 1992. The public sector as first user of innovations. Research Policy 21 (3) S.251-S.263.

De Moor, K., Saritas, O., Schuurman, D., Claeys, L., De Maerz, L. 2011. Exploring, imaging and creating future TV experience for/by users: a case study on innovation foresight. Paper delivered to the Fourth International Seville Conference on Future-Oriented Technology Analysis (FTA) - Seville 12-13 May, 2011.

Directors Forum (National IST Research Directors Forum Working Group on Public Procurement), March 2006. Pre-Commercial procurement of Innovation. A missing link in the European Innovation Cycle. Brussels, http://europa.eu.int/information society/research/key docs/documents/procurement.pdf.

DIUS. 2008. Innovation Nation, March 2008 http://www.dius.gov.uk/publications/ScienceInnovation.pdf

Edler J. 2008. Demand Policy for Innovation in EU CEE Countries. Working Paper 579, Manchester Business School.

Edler, J. ,Hommen, L., Papadokou, M., Rigby, J., Rolfstam, M.; Tsipouri, L.; Ruhland, S. 2005. Innovation and Public Procurement. Review of Issues at Stake, Study for the European Commission, final report. ftp://ftp.cordis.lu/pub/innovationpolicy/studies/full_study.pdf.

Edler, J. 2010. Demand Based Innovation Policy. In: Smits, R., Kuhlmann, S., Shapira, P. Innovation Policy - Theory and Practice. An International Handbook. Edward Elgar, Cheltenham, UK.

Edler, J., Edquist, C., Georghiou, L., Hommen, L., Hafner, S., Papadakou, M., Rigby, J., Rolfstam, M., Ruhland, S., Tsipouri, L. 2006. Innovation and Public Procurement. Review of Issues at Stake. Final Report. Brussels, ftp://ftp.cordis.lu/pub/innovationpolicy/studies/full study.pdf.

Edler, J., Georghiou, L. 2007. Public procurement and innovation-Resurrecting the demand side. Research Policy 36, 949-963.

Edler, J., Kuhlmann, S., Behrens, M. 2003. Changing Governance of Research and Technology Policy - the European Research Area. Edward Elgar: Cheltenham.

Edler, J., Meyer-Krahmer, F. and Reger, G. 2002. Changes in the strategic management of technology: results of a global benchmarking study. R\&D Management 32, 149-164.

Edquist, C., Hommen, L.,Tsipouri, L. 2000. Public Technology Procurement and Innovation. Kluwer: Dordrecht.

Edquist, C., Hommen, L.; Tsipuri, L. 2000. Public technology procurement and innovation, Kluwer Academic Pub., Boston. 
Etzkowitz H., Leydesdorff, L. 2000. The dynamics of innovation: from national systems and "mode 2" to a triple helix of University-industry-government relations. Research Policy 29 (2), 109-123.

European Commission , 2000. Innovation in a knowledge-driven economy. Brussels, 20.09.2000, COM(2000) 567 final.

European Commission, 2001. The Regional Dimension of the European Research Area. Brussels, 03.10.2001, COM(2001) 549 final.

European Commission, 2003. Research Investment Action Plan. Brussels.

European Commission. 2007. Communication from the Commission to the Council, the European Parliament, the European Social and Economic Committee and the Committee of Regions: A lead market initiative for Europe. Brussels, SEC(2007) 1729, SEC(2007) 1730.

European Commission , 2010. Regional Policy contributing to smart growth in Europe 2020. Brussels, 6.10.2010, COM(2010) 553 final.

Fildes, R. 1991. Research Foresight: priority setting in science. R\&D Management 21, 170171.

Flanagan, K., Uyarra, E.. Laranja, M. 2011. Reconceptualising the 'policy mix' for innovation. Research Policy 40 (5), 702-713.

Gavigan, J., Scapolo, F., Keenan, M., Miles, I., Farhi, F., Lecoq, D., Capriati, M., Di Bartolomeo, T. 2001. A Practical Guide to Regional Foresight, European Commission, DG JRC-IPTS, Seville, EUR20128en.

Gavigan, J.P., Scapolo, F. 1999. A comparison of national foresight exercises. Foresight 1 (6), 495-517.

Georghiou, L. 2001. Third Generation Foresight - Integrating the Socio-economic Dimension, Proceedings of the International Conference on Technology Foresight - the approach to and potential for New technology Foresight, NISTEP.

Georghiou, L. 2003. Raising EU R\&D Intensity: Improving the Effectiveness of Public Support Mechanisms for Private Sector Research and Development: Direct Measures 2003, EUR 20716.

Georghiou, L. 2004. Evaluation of behavioural additionality. Concept Paper to the European Conference on Good Practice in Good Practice in Research and Evaluation Indicators: Research and the Knowledge based Society. Measuring the Link, NUI Galway, 24 May 2004, http://www.forfas.ie/icsti.

Georghiou, L. 2007. Demanding Innovation—Lead Markets, Public Procurement and Innovation, NESTA Provocation 02. NESTA, London. 
Georghiou, L., Harper, J.C. 2008. FTA for research and innovation policy and strategy. Paper delivered to the Third International Seville Seminar on Future-Oriented Technology Analysis, Seville 16-17 October 2008.

Geroski, P.A. 1990. Procurement policy as a tool of industrial policy. International Review of Applied Economics 4 (2), 182-198.

Greenwood, D.J., Levin, M. 1998. Introduction to action research: social research for social change. Sage Publications, Thousand Oaks.

Hanney, S., Henkel, M., von Walden Laing D. 2001. Making and implementing foresight policy to engage the academic community: health and life scientists' involvement in, and response to, development of the UK's technology foresight programme. Research Policy 30(8), 1203-1219.

Hirst, P., 1994. Associative Democracy. Polity, Cambridge.

HM Treasury. 2007. Sainsbury Review of Science and Innovation. The race to the top. 05 October 2007.

Hollanders, H., Arundel, A. 2007. Differences in socio-economic conditions and regulatory environment: explaining variations in national innovation performance and policy implications. INNO-Metrics Thematic Paper, www.proinnoeurope.eu/admin/uploaded_documents/eis_2007_Socioeconomic_conditions.pdf

Howells, J. 2005. Innovation and regional economic development: A matter of perspective? Research Policy 34(8), 1220-1234.

Kok, W. 2004, Facing the Challenge. The Lisbon Strategy for Growth and Employment. Report from a High Level Group. November 2004, Luxembourg.

Koschatzky, K. 2005. Foresight as a Governance Concept at the Interface between Global Challenges and Regional Innovation Potentials. European Planning Studies 13, 619639.

Koschatzky, K. 2009. The uncertainty in regional innovation policy: some rationales and tools for learning in policy making, Working Papers Firms and Region, No. R6/2009, Fraunhofer ISI.

Laranja, M., Uyarra, E., Flanagan, K. 2008. Policies for science, technology and innovation: Translating rationales into regional policies in a multi-level setting, Research Policy 37 (5), 823-835.

Lember, V., Kalvet, T., Kattel, R. 2008. Urban competitiveness and public procurement for innovation. Mimeo, Institute of Humanities and Social Sciences, Tallinn University.

Lundvall, B.A. 1993. User-producer relationships, national systems of innovation and internationalization. Technology and the wealth of the nations-The dynamics of constructed advantage, 349-369. 
Macklin, L., Soroka, L. 2011. Linking Foresight to action: A health case study. Paper delivered to the Fourth International Seville Conference on Future-Oriented Technology Analysis (FTA) - Seville 12-13 May, 2011.

Martin, B.R. 1995. Foresight in Science and Technology. Technology Analysis and Strategic Management 7, 139-68.

May, G. 2009. Foresight and futures in Europe: an overview. Foresight 11 (5), 57-67.

Mowery, D., Rosenberg, N. 1979. The influence of market demand upon innovation: a critical review of some recent empirical studies. Research Policy 8 (2), 102-153.

OGC (Office of Government Commerce), 2004. Capturing Innovation. Nurturing Supplier's Ideas in the Public Sector. London.

Popper, R., Keenan. M., Butter, M. 2006. 2005 Mapping Report (The European Foresight Monitoring Network EFMN). Manchester: University of Manchester, PREST.

Porter, A.L., Ashton, B., Clar, G., Coates, J.F., Cuhls, K., Cunningham, S.W., Ducatel, K., Van der Duin, P., Georghiou, L., Gordon, T., Linstone, H., Marchau, V., Massari, G., Miles, I., Mogee, M., Salo, A., Scapolo, F., Smits, R., Thissen, W. 2004. Technology Futures Analysis: Toward Integration of the Field \& New Methods. Technological Forecasting \& Social Change, 71 (3), 287-303.

Porter, M.E. 1990. The Competitive Advantage of Nations. Free Press Edition, New York.

Porter, M.E. 1998. Clusters and the New Economics of Competition, Harvard Business Review 76 (6), 77-90.

Reijs, J. 1994. Foresight studies undertaken by the Ministry of Economic Affairs in the Netherlands. R\&D Management 24, 167-174.

Renn, O., Thomas, M. 2002. The Potential of Regional Foresight, Final Report of the STRATA-ETN Expert Group "Mobilising the regional foresight potential for an enlarged European Union - an essential contribution to strengthen the strategic basis of the European Research Area (ERA)". Luxembourg: European Communities.

Rothwell, R. 1986. Public Innovation Policy: To Have or to Have Not? R\&D Management, $16,25-36$.

Rothwell, R., Gardiner, P. 1989. The strategic management of reinnovation. R\&D Management, 19 (2), 147-160.

Roveda, C., Vecchiato, R. 2008. Foresight and Innovation in the context of industrial clusters: the case of some Italian districts. Technological Forecasting and Social Change 75 (6), 817-833.

Roveda, C., Vecchiato, R., Vercesi, P. 2004. Relationships between national and regional foresight: the lessons from experience. International Journal of Foresight and Innovation Policy 1 (3-4), 318-324. 
Roveda, C., Vecchiato, R., Verganti, R. Landoni, P. 2007. A new methodology for regional Foresight. International Journal of Foresight and Innovation Policy 3 (2), 218-234.

Shyu, J. Z., Chiu, Y. 2002. Innovation policy for developing Taiwan's competitive advantages. R\&D Management 32, 369-374.

Smith, J., STFPP Team Members, Masum, H., Bouchard, R., Kallai, P., Lockeberg, E. 2004. Using S\&T foresight to augment organizational tool kits: a Canadian institutionalentrepreneurial experiment. R\&D Management 34, 579-589.

Smits R., Kuhlmann, S. 2004. The rise of systemic instruments in innovation policy. International Journal of Foresight and Innovation Policy 1(1-2), 4-32.

Steen, M. van der, 1999. Evolutionary Systems of Innovation: Veblian Oriented Study to the Role of the Government Factor. Van Gorcun, Assen, The Netherlands.

Störmer, E., Truffer, B., Dominguez, D., Gujer, W., Herlyn, A., Hiessl, H., Kastenholz, Klinke, A., H., Markard, J., Maurer, M., Ruef, A., 2009. The Exploratory Analysis of Trade-Offs in Strategic Planning. Lessons from Regional Infrastructure Foresight. Technological Forecasting and Social Change. 76, 1150-1162.

Uyarra, E., Flanagan, K. 2009. Understanding the Innovation Impacts of Public Procurement. Working Paper 574, Manchester Business School.

Van Rijswijk, M., Kleijn, M., Janson, M., Menten, E. 2008. The process and experiences with creating user-driven innovation programmes in the Netherlands. Technology Analysis \& Strategic Management 20 (3) 309-320.

von Hippel, E. 1986.Lead Users, A source of novel product concepts. Management Science 32 (7), 791-805.

Wilkinson, R., Georghiou, L., Cave, J. 2005. Public Procurement for Research and Innovation - Developing procurement practices favourable to R\&D and innovation, European Commission, September 2005, EUR 21793 EN.

Yin, R. K. 2003. Case study research, design and methods. Sage Publications, Newbury Park. 


\section{Table 1}

A3T project: Attractiveness indicators used for evaluating application areas and related technologies

\section{ATTRACTIVENESS INDICATORS}

\section{a. Application perspectives in the global markets}

a.1 Size: the size of the sectors/markets (at a regional, national and global scale) that could be involved in the application area. The indicator was calculated as the average of the values (size in Euro million) provided by the experts.

a.2 Dynamics: potential growth of the EU and the global market, considering emerging trends and patterns of use, changes in regulation, policies of governmental bodies of other regions and countries (to which extent they are going to adopt and promote the application area, so increasing public demand?). The indicator was calculated as the average of the scores provided by the experts on a Likert scale, ranging from 1 (low growth) to 5 (high growth).

a.3 Technological basis: what are the main technologies required by the application area? This indicator analyses the technological basis which underlies the application area and measures the extent to which the demand for the application area depends on future development of emerging technologies.

a.4 Technological stage: which is the stage of the technology within its life cycle? According to the stage, one can classify technologies in the following way: Embryonic technologies: they are in the first stages (fundamental and applied research) so their potential benefits are still uncertain. If the industrial firms of a region want to become leaders in such a technology, they must make investments at this stage, when competition is not high yet, but uncertainty and technical risks are maximum. Growing technologies: their economical relevance is unambiguous, but if one starts investing in a technology at this stage only, following the first investors, it may be very difficult to become a leader (it may be feasible in some niches which are still free). Mature technologies: they have already reached the upper limit of growth: competition is high, strong opportunities are few.

a.5 Pervasiveness: pervasiveness measures the extent to which future developments reached in the technologies required by the application area will enable future developments in other applications and other technological areas. The indicator was calculated as the average of the scores provided by the experts on a Likert scale, ranging from 1 (low pervasiveness) to 5 (high pervasiveness).

b. Coherence with local demand and policy

b.1 Application power: to what extent the applications in the area are governed at a local level (regional or sub-regional). The indicator was calculated as the average of the scores provided by the experts on a Likert scale, ranging from 1 (low power) to 5 (high power).

b.2 Investment power: to what extent the investments in research and innovation required to develop new products and services in the application area have a dimension compatible with the resources available at a regional and sub-regional level? The indicator was calculated as the 
average of the scores provided by the experts on a Likert scale, ranging from 1 (low power) to 5 (high power).

b.3 Coherence: to which extent the application is coherent with the demands of local citizens and the policy of the local governmental bodies? Is likely to take place a relevant demand at a local level? Are the improvements enabled by the innovation coherent with the policy of the regional government? The indicator was calculated as the average of the scores provided by the experts on a Likert scale, ranging from 1 (low coherence) to 5 (high coherence).

b.4 Pubic procurement: to which extent the local public administrations (or other institutions linked with the latter ones) may be clients of the application? Are the regional governments and other local governmental bodies (province administration, municipalities) able to express a relevant demand for the application, so boosting private investments for the development of the related technologies, most of all when it is at an embryonic stage? The indicator was calculated as the average of the scores provided by the experts on a Likert scale, ranging from 1 (low potential for public procurement) to 5 (high potential).

b.5 Partnership: to which extent the application required to cooperate within a network of private and public partners, at a local, a national and an international level? To which extent public research centers and industrial players have to be integrated one with each other? If so, the application is very relevant, because the intervention of the regional government may be a key driver, enabling the achievement of results that otherwise cannot be reached. The indicator was calculated as the average of the scores provided by the experts on a Likert scale, ranging from 1 (low potential for partnership) to 5 (high potential). 


\section{Table 2}

A3T: Position (feasibility) indicators used for evaluating application areas and related technologies

\section{POSITION INDICATORS}

c. Application and scientific knowledge

c.l Knowledge: it evaluates the availability in the region of the competences and the know-how which underlie the application area - compared with other regional and national systems at the international level. The indicator was calculated as the average of the scores provided by the experts on a Likert scale, ranging from 1 (low availability) to 5 (high availability).

c.2 Human resources: it measures, approximately, the number of researchers currently involved in $\mathrm{R} \& \mathrm{D}$ activities related to the application area (and related technological basis). It measures the approximate number of researchers that the R\&D system of the region needs to reach a position of excellence at international level in the development of the application area. The indicator was calculated as the average of the values (numbers of researchers) provided by the experts.

c.3 Educaton: the availability in the region of an educational system suited to contribute to develop the required competencies, both in terms of quality and quantity. The indicator was calculated as the average of the scores provided by the experts on a Likert scale, ranging from 1 (low availability) to 5 (high availability).

c.4 Infrastructures: availability at a local level of infrastructures (instruments, laboratories) required for developing the application area. The indicator was calculated as the average of the scores provided by the experts on a Likert scale, ranging from 1 (low availability) to 5 (high availability).

d. Local demand and position of the industrial system

d.1 Access to lead markets. This indicator relates to the lead-markets for the applications areas. It measures the availability in the regions of lead users for the application areas, namely clients with needs and application knowledge at the state of art at an international level. The indicator was calculated as the average of the scores provided by the experts on a Likert scale, ranging from 1 (low availability) to 5 (high availability).

d.2 Competitiveness: it relates to the competitiveness of the local industrial system. To which extent the local industrial players that develop products and services related to the application area are able to compete at an international level? The indicator was calculated as the average of the scores provided by the experts on a Likert scale, ranging from 1 (low competitiveness) to 5 (high competitiveness).

d.3 Re-convertibility: to which extent industrial players coming from other sectors and markets may develop the application area? May the competencies developed for other applications be converted? Are there entry barriers? If so, how much are they huge? The indicator was calculated as the average of the scores provided by the experts on a Likert scale, ranging from 1 (low convertibility) to 5 (high convertibility). 
d.4 Start-up: potential establishment of new firms which develop products and services for the application area. The indicator was calculated as the average of the scores provided by the experts on a Likert scale, ranging from 1 (low potential) to 5 (high potential).

d.5 Coverage: availability in the region of the different industrial competencies required to develop the application area, at least for a relevant part. We consider here the structure of the industrial system of the region, the access to complementary technologies and industrial resources. The indicator was calculated as the average of the scores provided by the experts on a Likert scale, ranging from 1 (low availability) to 5 (high availability). 


\section{Table 3}

Matching application areas with emerging technologies: the A3T application areas and pilot projects for the macro-fields of Healthcare, Energy and Environment, Food and Agriculture

\begin{tabular}{|c|c|c|c|c|}
\hline \multicolumn{5}{|c|}{ Healthcare } \\
\hline \multirow[t]{2}{*}{ Application area } & \multirow[t]{2}{*}{ Pilot project } & \multicolumn{3}{|c|}{$\begin{array}{l}\text { Technological } \\
\text { area }\end{array}$} \\
\hline & & ICT & $\mathrm{BIO}$ & MAT \\
\hline \multirow{2}{*}{ Elderly people } & Remote assistance and diagnosis services & $\mathrm{X}$ & & \\
\hline & Re-design of furniture and home environment & $\mathrm{X}$ & & $x$ \\
\hline $\begin{array}{l}\text { Assistance to } \\
\text { disable and } \\
\text { chronically sick } \\
\text { people }\end{array}$ & $\begin{array}{l}\text { ICT-based remote systems for control, monitoring and home } \\
\text { assistance }\end{array}$ & $\mathrm{X}$ & & \\
\hline \multirow{3}{*}{$\begin{array}{l}\text { Healthcare } \\
\text { infrastructures }\end{array}$} & $\begin{array}{l}\text { Improvement of management efficiency: control and } \\
\text { monitoring of healthcare infrastructures }\end{array}$ & $\mathrm{X}$ & & $\mathrm{X}$ \\
\hline & Automated equipment for the towing of beds and stretchers & $\mathrm{X}$ & & $\mathrm{X}$ \\
\hline & Automated robotic systems for blood sampling & $\mathrm{X}$ & & $\mathrm{X}$ \\
\hline \multirow{4}{*}{$\begin{array}{l}\text { Innovative } \\
\text { solutions for } \\
\text { diagnosis and } \\
\text { treatment }\end{array}$} & Advanced-material based prostheses & & & $\mathrm{X}$ \\
\hline & Nanotechnology-based diagnostic tools & $x$ & $\mathrm{X}$ & $x$ \\
\hline & Nanotechnology-based drugs & $X$ & $x$ & $X$ \\
\hline & $\begin{array}{l}\text { Treatment and rehabilitation of disabled people: treatment } \\
\text { of the pathologies of the nervous system }\end{array}$ & $\mathrm{X}$ & $\mathrm{X}$ & $x$ \\
\hline
\end{tabular}


Table 3 (continued)

\begin{tabular}{|c|c|c|c|c|}
\hline \multicolumn{5}{|c|}{ Energy and Environment } \\
\hline \multirow[t]{2}{*}{$\begin{array}{l}\text { Application } \\
\text { area }\end{array}$} & \multirow[t]{2}{*}{ Pilot project } & \multicolumn{3}{|c|}{$\begin{array}{l}\text { Technological } \\
\text { area }\end{array}$} \\
\hline & & ICT & BIO & MAT \\
\hline \multirow{2}{*}{$\begin{array}{l}\text { Logistics and } \\
\text { mobility }\end{array}$} & $\begin{array}{l}\text { Info-mobility networks: ad-hoc vehicular } \\
\text { networks and infrastructures for traffic } \\
\text { control, security and the delivery of info- } \\
\text { mobility services }\end{array}$ & $x$ & & \\
\hline & Intermodal transportation & $x$ & & \\
\hline \multirow{2}{*}{$\begin{array}{l}\text { New } \\
\text { (renewable) } \\
\text { energy } \\
\text { sources }\end{array}$} & Solar cells: beyond silicon & & & $x$ \\
\hline & Materials for hydrogen and storage & & & $x$ \\
\hline $\begin{array}{l}\text { Environmental } \\
\text { networks }\end{array}$ & $\begin{array}{l}\text { Sensor networks for environment } \\
\text { protection }\end{array}$ & $x$ & & $x$ \\
\hline Energy saving & Home automation for energy saving & $x$ & & $x$ \\
\hline
\end{tabular}


Table 3 (continued)

\begin{tabular}{|c|c|c|c|c|}
\hline \multicolumn{5}{|c|}{ Food and Agriculture } \\
\hline \multirow[t]{2}{*}{ Application area } & \multirow[t]{2}{*}{ Pilot project } & \multicolumn{3}{|c|}{ Technological area } \\
\hline & & ICT & $\mathrm{BIO}$ & MAT \\
\hline \multirow{4}{*}{$\begin{array}{l}\text { Enhancement } \\
\text { (functionalization and } \\
\text { nutritional } \\
\text { enrichment) of } \\
\text { traditional food } \\
\text { products of Lombardy }\end{array}$} & $\begin{array}{l}\text { From typical to functional: innovation in dairy } \\
\text { farming }\end{array}$ & & $\mathrm{x}$ & \\
\hline & Functional foods in marginal areas & & $\mathrm{x}$ & \\
\hline & $\begin{array}{l}\text { Wine growing in Lombardy: beyond fine }(A O C) \\
\text { wines }\end{array}$ & & $x$ & \\
\hline & Functional foods for elderly people (see Table 4) & & $\mathrm{x}$ & \\
\hline $\begin{array}{l}\text { Enhancement of } \\
\text { natural raw materials }\end{array}$ & $\begin{array}{l}\text { Biotechnologies for agriculture and farming: } \\
\text { genomics in food processing }\end{array}$ & & $\mathrm{x}$ & \\
\hline \multirow{2}{*}{$\begin{array}{l}\text { Improvement of } \\
\text { production and } \\
\text { distribution processes }\end{array}$} & Active films for food packaging & $x$ & & $x$ \\
\hline & Traceability and security: molecular diagnostic & & $\mathrm{x}$ & $\mathrm{x}$ \\
\hline
\end{tabular}




\section{Table 4}

Pilot project (general guidelines): Functional foods for elderly people (Application area: Enhancement - functionalization and nutritional enrichment of traditional food products of Lombardy)

The enhancement of functional and nutritional features of food products, first of all vegetables, through genomic and proteomic technologies, might be very effective in order to face pathogenetic dynamics of chronic degenerative diseases. Generally, there is a lack of attention regarding the diet of old people, and thereby the lack of specific products suited to respond to specific nutritional needs related to the treatment or prevention of typical pathologies, or simply to the improvement of health and life conditions.

A great part of the Lombardy food sector has the potential to develop in such direction, and thereby to add considerable value to a relevant number of products for which health claims have been certified. In this context, functional products are not confined to market niches, but actually address a growing number of citizens given the ageing of population in the EU countries and the diffusion of old age-related diseases. The prevention of such diseases through ad-hoc diets and functional products might have a fundamental role in health policies, by reducing significantly the expenditure for the treatment of old-age related diseases and by improving at the same time the quality of life of these people.

On the other hand, some psychic disorders make patients addicted to considerable food requirements, and thereby to the continuous consumption of food products; more generally, old Lombard people keep on requiring gastronomy foods typical of their local tradition and habits, despite these products being not more compatible with their metabolism. Also in such cases, the development of functional foods might fulfill the requirement of local citizens and improve their quality of life. 


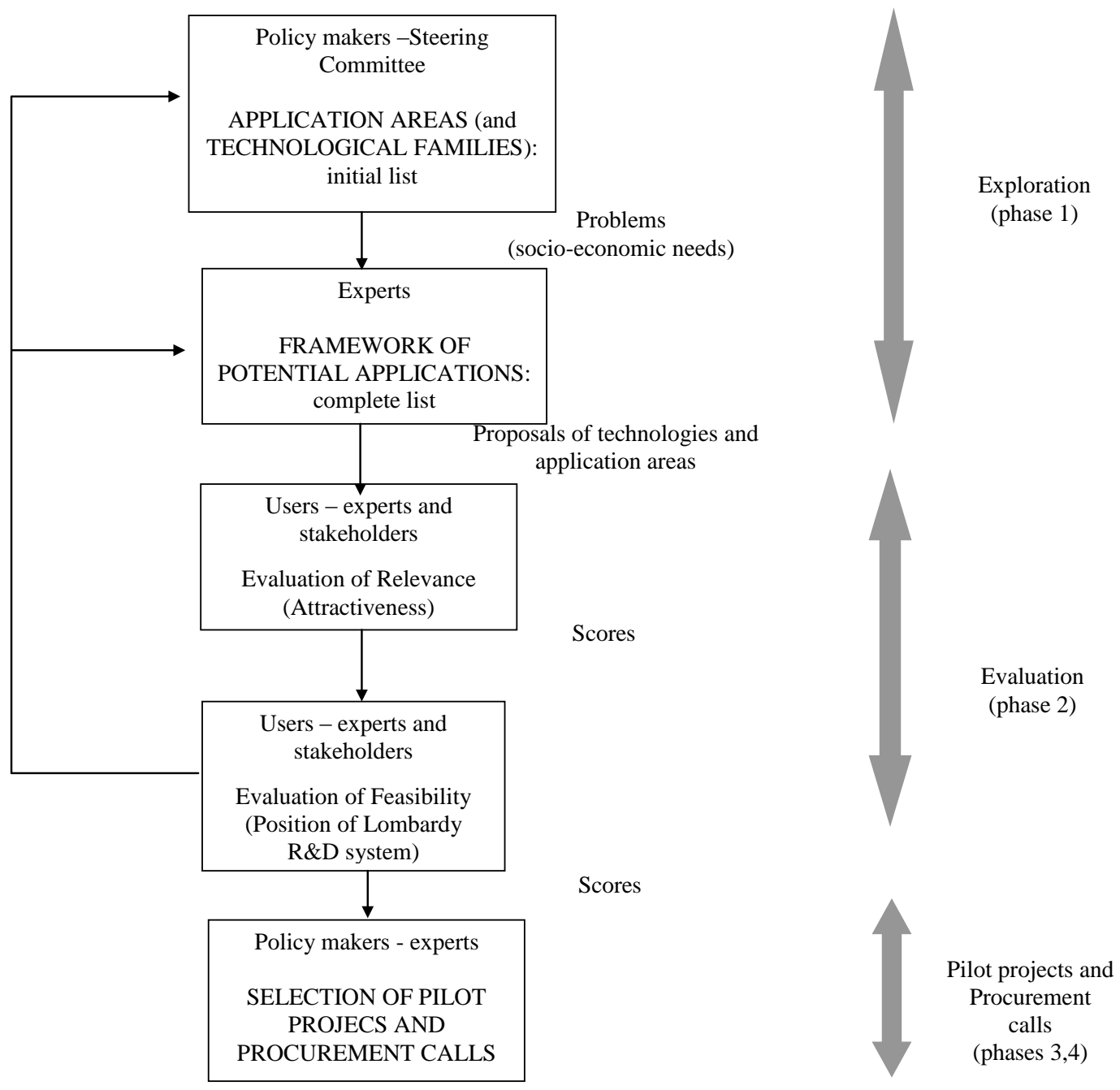

Figure 1. A3T project: methodology and organizational process 